\title{
Creating the Image of Bucharest in art (1850 - 2017)
}

\author{
Bob Jarvis* \\ University of Sussex, United Kingdom
}

\begin{abstract}
'Kunstgeographie' - the study of the geographical dimension of art is a relatively undeveloped field, at least in English language studies. This article, which is developed from art history research at Sussex University, studies the images of Bucharest in art as it grew from a loosely organised collection of village-like groups to the capital of a new state - over the same period that Romanian art broke away from the religious art of the Orthodox church to become westernised as exchanges with western Europe grew. The growth of Bucharest has been analysed by Guiseppe Cina (2010) in four distinct phases, and these are used as the basis of this analysis.
\end{abstract}

Key Words: Kunstgeographie, Bucharest, Romanian art, urban development.

Article Info: Received: February 7, 2018; Revised: May 4, 2018; Accepted: May 10, 2018; Online: May 25, 2018.

\section{The background to topographical art and "geography of art" and the urban development of Bucharest}

'Kunstgeographie' (the geography of art) can be traced back to the 19th century and has undergone something of a revival in recent years. Thomas DaCosta Kaufmann (2004) relates it to the recent "spatial turn" in some areas of philosophy - he refers to the work of Foucault and Henri Lefebre (Kaufmann, 2004, 30 ) on the one hand and also the recognition of a geography of art that emerged in the 19th century in France and Germany. Its revival in the post-war period has been in Eastern Europe where boundaries and national identities have been fluid. Kaufmann's definitive revival text is rich in examples from Poland, Slovakia, and Hungary and he comments how art history largely ignores two thirds of Europe "and the area east of the Oder in almost any

* Correspondence address

Address: 41, Addison Road, HOVE, BN3 1TQ, United Kingdom.

Phone: (0)1273 724811 | Email: rkj100@yahoo.com

(C)2018 Human Geographies; The authors

c) (1) This work is licensed under a

Creative Commons Attribution 4.0 International License. DOI:10.5719/hgeo.2018.121.1 
period" (Kaufmann, 2004, 190). Paradoxically one of the best known works is 1956 Nikolaus Pevsner's The Englishness of English Art which adopts a wide timeframe. Kaufmann concludes his survey with a note of several important conferences at the end of the 20th Century which "consciously evoked" Kunstgeographie (Kaufmann, 2000,103-4).

There are few extended works in English covering the history of Romanian art This paper discusses the capital of Romania, Bucharest as its image is projected in art and combines the author's backgrounds in both art history and urbanism to develop an original perspective.

Bucharest grew from a collection of villages formed by practical necessities and topographical constraints. The establishment of an independent Romania consolidated the role of Bucharest - capital of Wallachia since 1659- as the capital of the new country, favourably located in a marshy landscape between the Carpathian mountains to the north and west and the Black Sea coast to the south and east.

As Romania emerged as a nation state its art rapidly westernised: artists began to be trained abroad, and Romania and Romanian scenes began to be pictured in versions of 'western' artistic styles. The image of Bucharest was no exception and this paper studies the parallel transformation of Bucharest into a 'western' capital city. Following the defeat of the Ottomans at Vienna the cultural grip of the Ottoman empire loosened and there was a rapid establishment of western fine art practices in the 19th century (Florea, 1983). The key question explored here is the connection between architectural changes in Bucharest and in the representation of the city in art, bringing together the fields of art history, urban geography and Romanian studies.

\section{Four significant periods: the growth of the city and of art}

In his comprehensive account of the development of Bucharest Guiseppe Cina (2010) identifies four periods and styles of urbanization after the 'village-city'. These four stages of urban development provide a robust framework for analysis in which distinct changes and patterns of urban development can be identified:

- 'the Paris of the Balkans and historicist architecture' from about 1880 with the rapid growth of Bucharest it was necessary to borrow and import styles and architects, although by the turn of the century a historicist Neo-Romanian National Romanticism which borrowed elements of Romanian architecture began to be used alongside classical and romantic styles.

- 'the new modernity - between tradition and innovation' (from 1912 to the outbreak of World War II) - saw the emergence of Romanian architects working in an eclectic range of styles running through Art Nouveau, Art Deco and Functionalism.

- 'the socialist city - from rationalism to post-modern' (from 1946 to 1989) - socialist architecture and planning itself evolved from the almost classical modernism of the early post war years through the huge scale of the blocuri running along existing roads and leaving islands of traditional housing behind them to the post-modernist elaborations of Ceauşescu with its vast areas of clearance and demolition. 
-'post 1989: the difficult return to Europe' (from 1989 to the present) - with the collapse of state control and the ineffectiveness and inherent corruption in the post 1989 development, the result has been a chaotic (or from a different critical standpoint, visually exciting) collage and juxtaposition of styles and forms.

Cina's breakdown of the architectural history of Bucharest provides a coherent and argued historical outline. This paper will explore the extent to which these periods are also present in the visual representations of the city and whether the attentions and concerns of artists are the same, by examining paintings more systematically - are they showing the same city?

A secondary question - can these themes be traced in other art forms? remains to be explored, but a preliminary exploration of Romanian literature available in translation suggests that this may be so and a few examples are discussed in each section.

\section{The Paris of the Balkans and historicist architecture (from about 1880)}

Although the image of Bucharest promoted from this period is one of the new French - influenced and styled grand buildings and streets, the painters of this period seem to have preferred the seedier backgrounds and side streets in their topographical work (Figure 1, Figure 2). The public image of Parisian style and elegance promoted through postcards and photographs emphasising the grand facades and elegant streets. Cina includes many examples of these (Cina, 2010). If there had been a thoroughly developed beaux-arts school in Bucharest paintings that commemorated these in the manner of French paintings of Paris of the period might have been produced. Another explanation might be that the appearance of many of these streets in Bucharest was, at street level, far from grand - the photographs that Cezara Muncenic includes in her book Străzi, Piețe, case din Vechiul Bucureşti (2004) show new buildings overwhelmed with the clutter of advertising and displays.

Painterly preferences were for the picturesque and showed a very different, informally composed city full of decay and collapse. Ştefan Lucian's painting has a title that demonstrates this contrast - 'The Devils Slum' - an incoherent group of much altered modest houses with additions of ad-hoc steps and lean-to's surrounded by debris and detritus - the opposite of the careful domesticated formalism of Micul Paris sets a bitter note.

There is no shortage of paintings of the picturesque decay and confusion in the backstreets of Micul Paris. The fascination of picturesque decay continued into the 1920's. The visual possibilities of tumbling roofscapes and irregular groupings of poor buildings continued, giving rise to a different rendering of Bucharest not as a great formal city but as a picturesque jumble. The reality of this pattern is confirmed in Nicolae Ionescu's series of photographs of the 1930's (Ionescu, undated) which showed the truth behind the facades of Micul Paris - a city where rag pickers abound, and sewage outfalls are used for washing.

There are two minor examples of where something approaching the grand style was realised. Nicolae Dărăscu (1883-1959) trained in Paris and returned to Bucharest in 1918 where he concentrated on urban scenes in an impressionist manner, responding to the qualities of light and weather. His paintings of Calea 


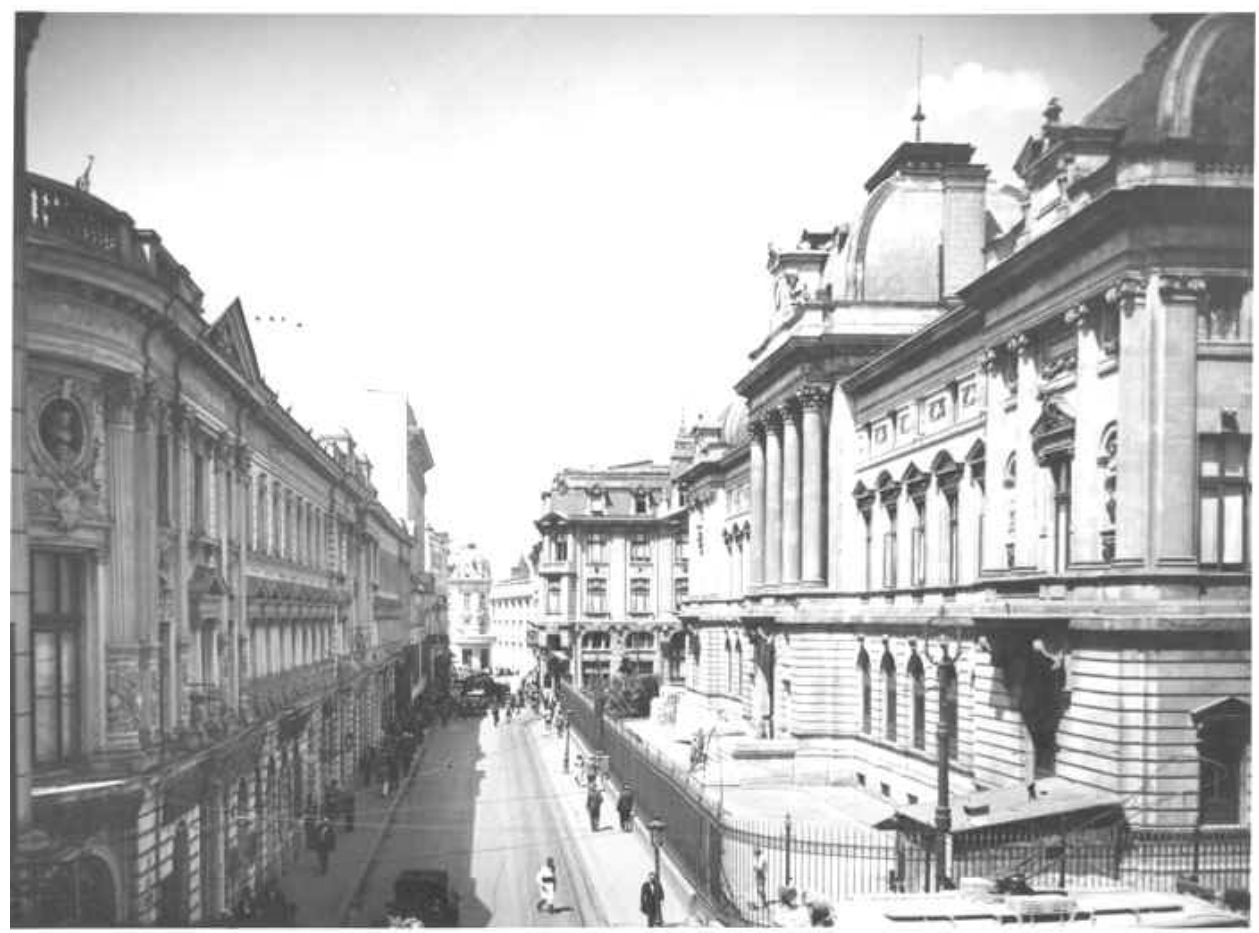

Figure 1. Micul Paris - the grand manner adopted in the business district. The State Bank on Lipscani Street (1882- 1890 architects Cassien Bernard and Albert Galleron with Nicolae Cerchez and E. Băicoianu)

Source: Public Domain. File: Bancanationala anii1920.jpg

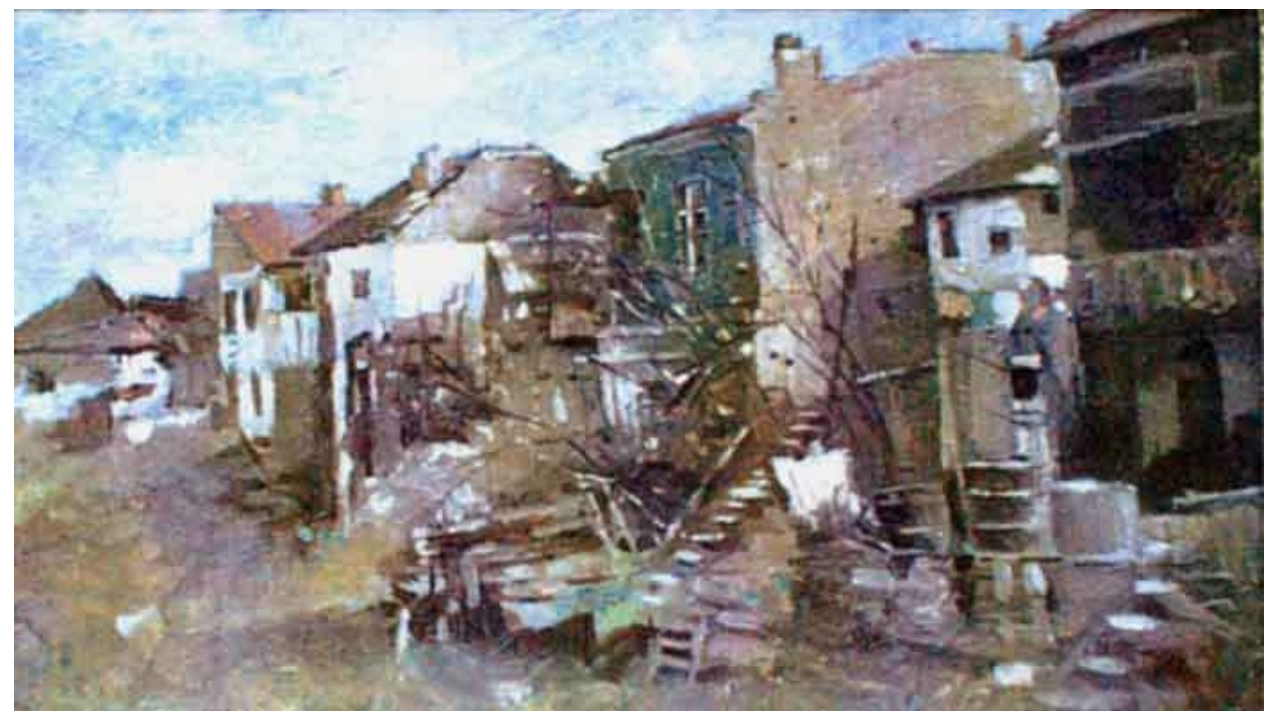

Figure 2. The other side of Micul Paris: Stefan Luchian: Mahalaua dracului 1898 Source: Public Domain. https://www.wikiart.org/ (Muzeul Național de Artă al Româiniei - Bucureşti, Ulei pe pânză (oil on canvas) $35,5 \times 60,5 \mathrm{~cm}$ ) 
Victoriei in the rain date from the 1930's, evoking these busy grand spaces. Variations of the work can be found in the collection of the National Art Museum of Romania (inv. 2,983) and the collection of the Bucharest Museum. Calea Victoriei, however, was not a new straight planned street but followed the old alignment askew from the new grid of streets, despite being though lined with imposing buildings.

More suburban than urban: another aspect of Bucharest. The idea of Bucharest as a place of gardens provides a starting point for another strand of Impressionist imagery. Gutkind includes some short comments on the openness and greenness of Romanian cities "clothed in verdure, the houses almost lost to sight among trees and flowers, parks acting as links among new building ensembles" (Members of the Central Research Institute for Building Architecture and Planning, 1972). Florin Machedon, Luminiţa Machedon and Ernie Scoffham (1999) also have given this idea particular attention. Well into the 20th century Iosof Iser (1881-1958) shows in one painting a leafy view of Bucharest (Busuioceanu, 1930) while Ion Theodorescu Sion (1882- 1939) left two paintings of Bucharest Gardens in a style that tended towards a neoByzantine boldness (Călinescu, 1968).

Though written in 1984 Gabriel Adamșteanu's Wasted Morning (Dimineaţa Pierdută, English translation 2011) presents a complex and overlapping series of cross-sections of a varied and rich Bucharest seen through the life of the chatty and gossipy Vica Delea, which is closer to the painters' preference for the backstreets of Micul Paris.

\section{The new modernity - between tradition and innovation (from about 1912 to the outbreak of World War II)}

Between 1918 and 1939 Bucharest was a thriving, and very much a cosmopolitan European city with a rich and varied culture. Its architecture took on the new international modernist styles, and the city was a hub of the interchange of artists and ideas. In documenting the Romanian roots and connections to DADA Tom Sandquvist (2006) gives a vivid image of this brief flowering which would be buried with the abdication of King Michael and the establishment of Communist rule after WWII. Sandquvist discusses at length John Reed's 1916 visit when Reed found nothing original there where everything is borrowed even the King and the style of his palace (Reed, 1916). But Sandqvist concludes that this was the city to which the Romanian Dadaists would continually return and take part in its artistic and creative life (Figure 3, Figure 4, Figure 5).

Though excited by and attracted to the city and contributing to its architecture, there are few paintings of Bucharest in this period. Marcel Janco (who was involved with DADA and his contribution was the designer of key modernist buildings in Bucharest notably Villa Jean Fuchs 1927) in his description of Bucharest as a "city of accidents" captures the excitement of the confusion and variety of the townscape - a quality that is still apparent - though with more layers added (Janco, 1926).

DADA is internationally the best-known strand of the avant-garde in Romania in the early 20th century, but a recent exhibition and its catalogue 


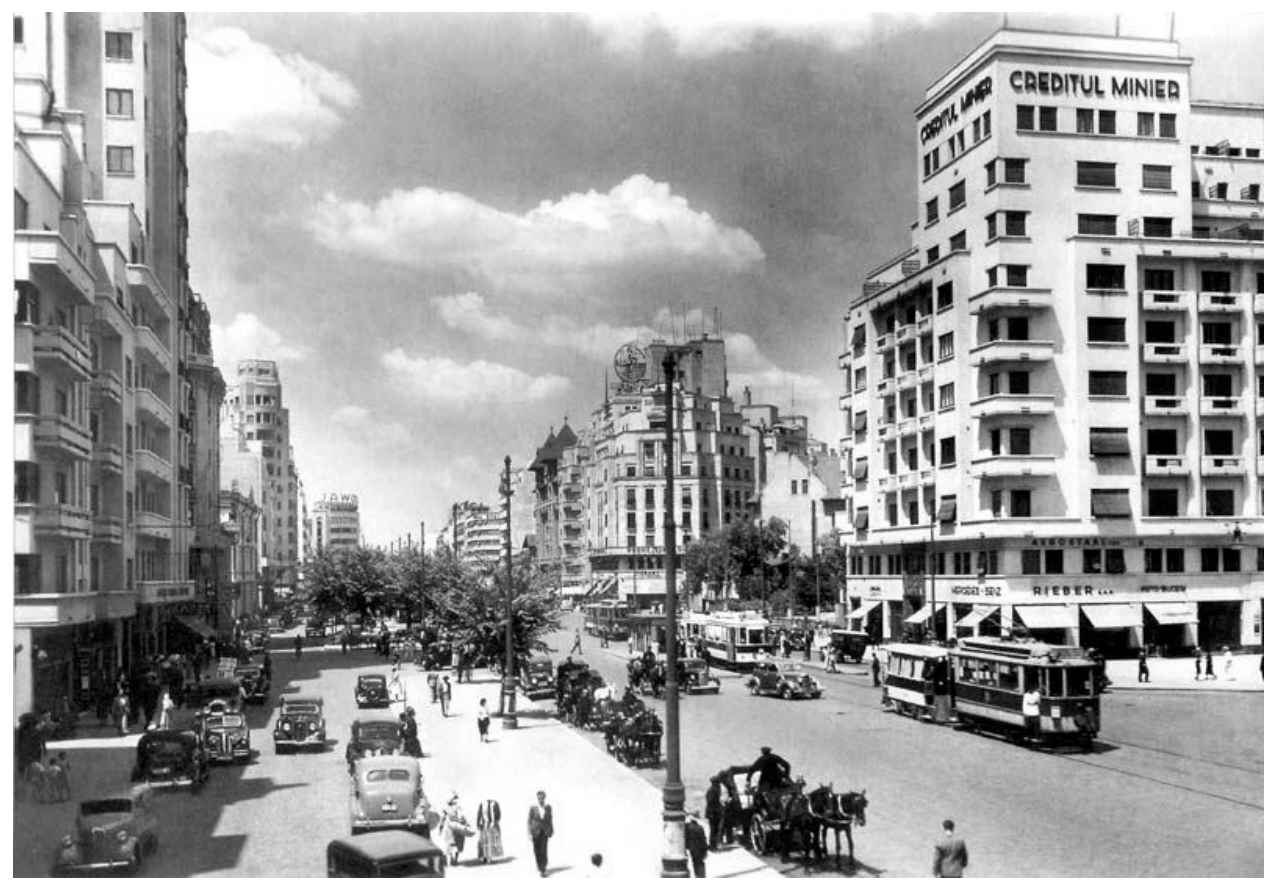

Figure 3. The Jazz age city: Bulevardul I. C. Brătianu

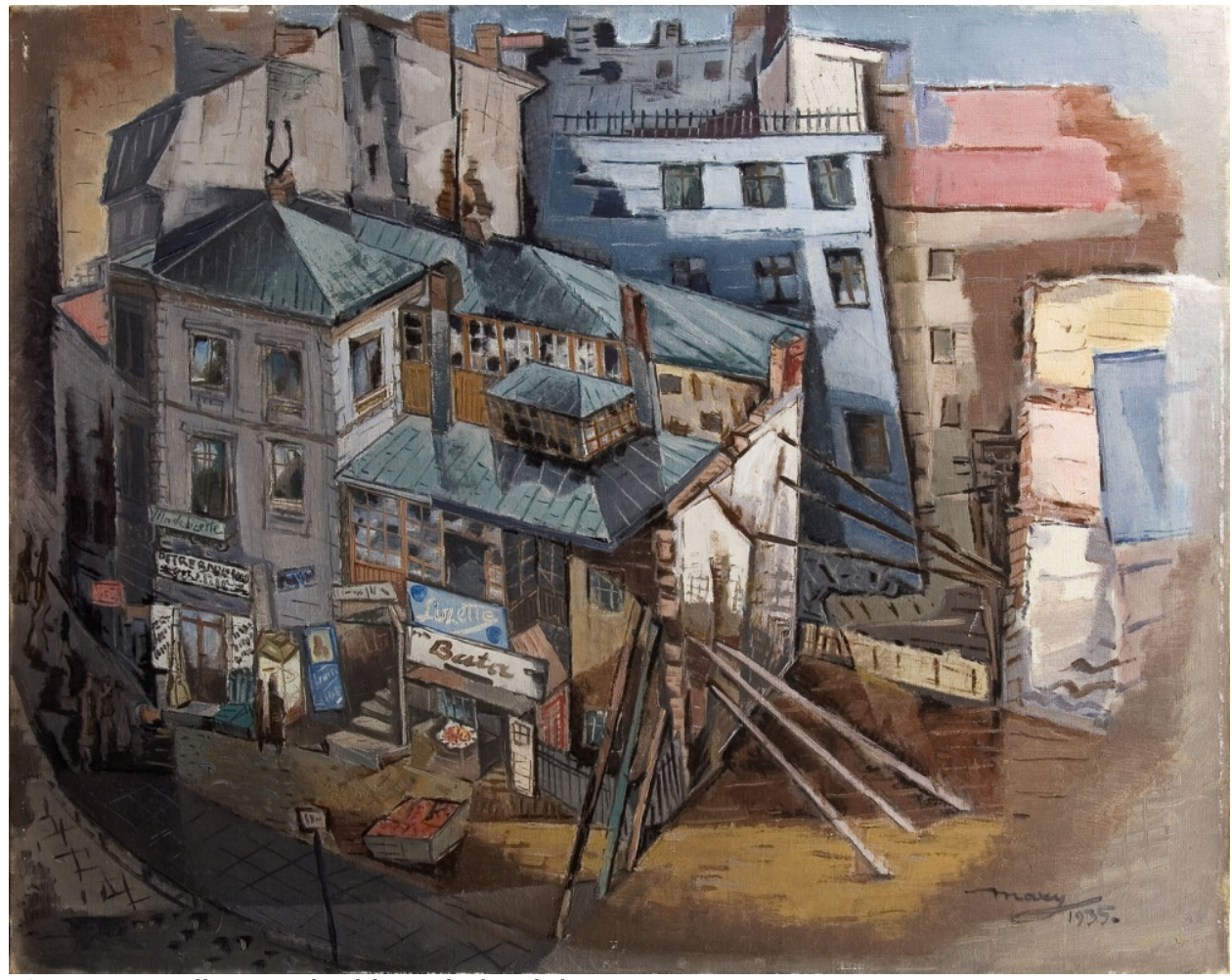

Figure 4. Collapsing buildings behind the new streets. Max Herman Maxy St. George Place in Crotches, 1935.

Source: Public Domain SOURCE National Museum of Art Romania, Romanian Modern Art Gallery 


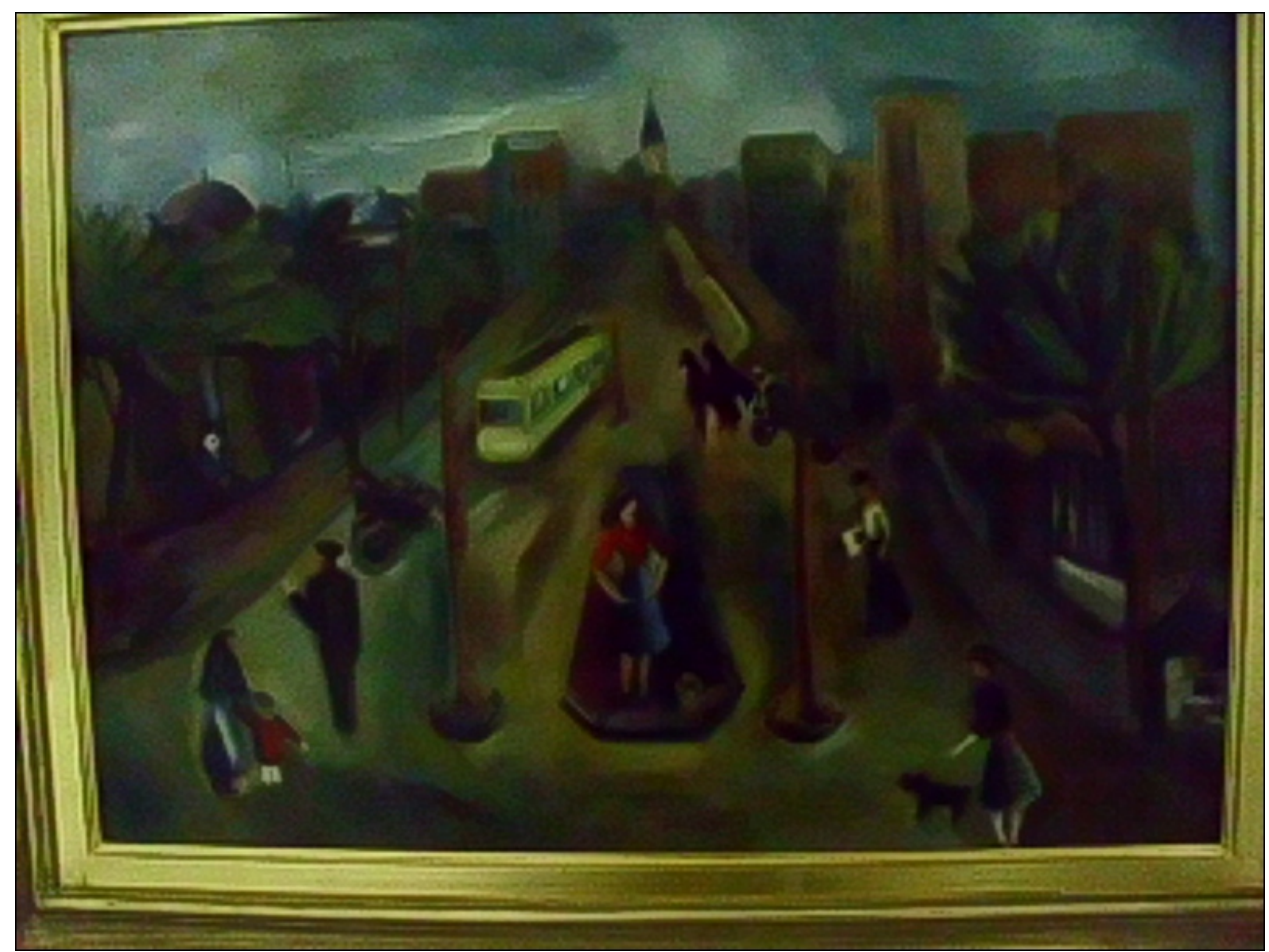

Figure 5. Frozen Movement: frozen moments. Margerita Sterian (1897-1992) Peisaj Source: Authors photograph of painting in Romanian National Gallery taken with permission for personal and academic use

(Kessler and Vlasiu, 2011) presents a more balanced view; the interruption and disjuncture that followed fifty years of communism have created many gaps in history, and they begin to trace these gaps in history. This exhibition included relatively few urban scenes, but there is much discussion of urbanism as a theme. A statement from the first issue of Integral the (equivalent of a Constructivist journal in Romania): "We definitely live under the zodiac of the city" (Vlasiu, 2011). This period showed a great range of painting styles- indeed the opening words of the catalogue are an apology (Kessler and Vlasiu, 2011).

There were relatively few urban scenes in that exhibition although at the same time grand axial modernist schemes were the dominant mode of architecture. The new Boulevard I. C. Brătianu was cut through the maze of lanes and the outer areas, new housing areas such as Vatra Luminoasă adopted a modernist, geometrical style as well.

Vlasiu (2011) notes one modern-styled building as significant: the telephone 'palace' painted by Nicolae Dărăscu. It was a striking modernist intervention in the mixed streetscape of Calea Victoriei the first major modernist building on Calea Victoriei, and at $52.5 \mathrm{~m}$ high was the nearest Bucharest came to a skyscraper until the post-communist era. It was welcomed a flagship for the new age: "this is how the whole of Bucharest would look which if we had been allowed... if its builders had been clever enough..." (Tudor, 2000).

For artists, it was the dynamics of the industry and the vibrancy of city life that was their focus in this period. Lucian Grigorescu, a highly regarded painter and a member of the Romanian Academy, saw realism as the most important 
aspect of painting: "I do not want to make allegory; I think that this level of expression is obsolete, outdated" (Prut, 2016). His city views are painted with loose brushwork and blurred edges as if the whole city is trembling.

For other artists even when representing static buildings and street scenes, the treatment of these ordinary urban scenes is given extra dynamism by fragmentation of the view and interlocking perspectives. Max Herman Maxy (1895-1971) who was also a stage designer and worked for Jewish Theatre companies (Mansbach, 1999; Pavel 1996; Uniunea Arhitecților din România, 1994) presents a whirling view of a building that seems to be in danger of collapse; Alexandru Phoebus's problematic urbanism uses distortions of perspective (Kessler and Vlasiu, 2011).

It is the dynamics of street-life that is the focus - whether in Jean al. Steriade's (1880-1956) Whitewashers a solid and sturdy group about to begin their task is painted in a very conventional manner even used on postage stamps (Deac, 1962) or a city square filled with diverse and disparate activity centred around a female figure who is posed almost in dance Margarita Sterian's Peisaj (Sterian, undated) or Marcel Iancu's rendering of a courtyard with washing and washerwomen caught in momentary angular patterns.

For some the drama of industrial plant and its contrast with the natural landscape offered a new perspective: though industrial plant was scattered throughout Bucharest there were no paintings of these sites though Arthur Segal's The Railway catches something of these disjunctures. "Sometimes, in the vast, uncanny space dominated by trains, virtually prolonged ad infinitum along the railway tracks, the silhouette of a signaling box and/or of a human figure is used as contrapuntal composition technique, precisely in order to provide a balancing sense of warmth, familiarity to the otherwise cold railway landscape for example in Train at night (Lionel Walden, c1890) or Railway (Arthur Segal, 1910)" (Purcar, 2016).

By comparison with the angular forms of modern architecture or the poetry and performances of DADA and considering the chaos and turmoil of the landscape of Bucharest its representation in art was somewhat conventional. Artists focussed more on the excitement and dynamics of city life for their subject matter. Marcel Iancu published A Utopian Vision for Bucharest which calls for a new geometrically inspired planning and looks to Le Corbusier for a new 'prophetic and bright' urbanism of which would call for the reorganisation of land parcels, wide streets and tall buildings. "I feel it's imperative that Bucharest should be reconstructed; I have tried to sketch a new urban orientation that can be perceived as utopian.......Its material is huge, its means are revolutionary while its plan needs to be utopian." (Iancu, 2010).

But these do not seem to have inspired a new visionary school of paintings of the city. Just as in the 1890's and 1900's there are no grand beaux-arts paintings so in the 'jazz age' there was no great futuristic painted vision of Bucharest. Its chaos and discord were enough.

The same conclusions might be drawn from writings of the 1930's. Both Mircea Eliade's Diary/Novel of a Short Sighted Adolescent (written in 1932 but not published until 2016) and Mihail Sebastian's For Two Thousand Years (1934, translation 2016) are rich accounts of interactions and human life and meetings which make the city. 


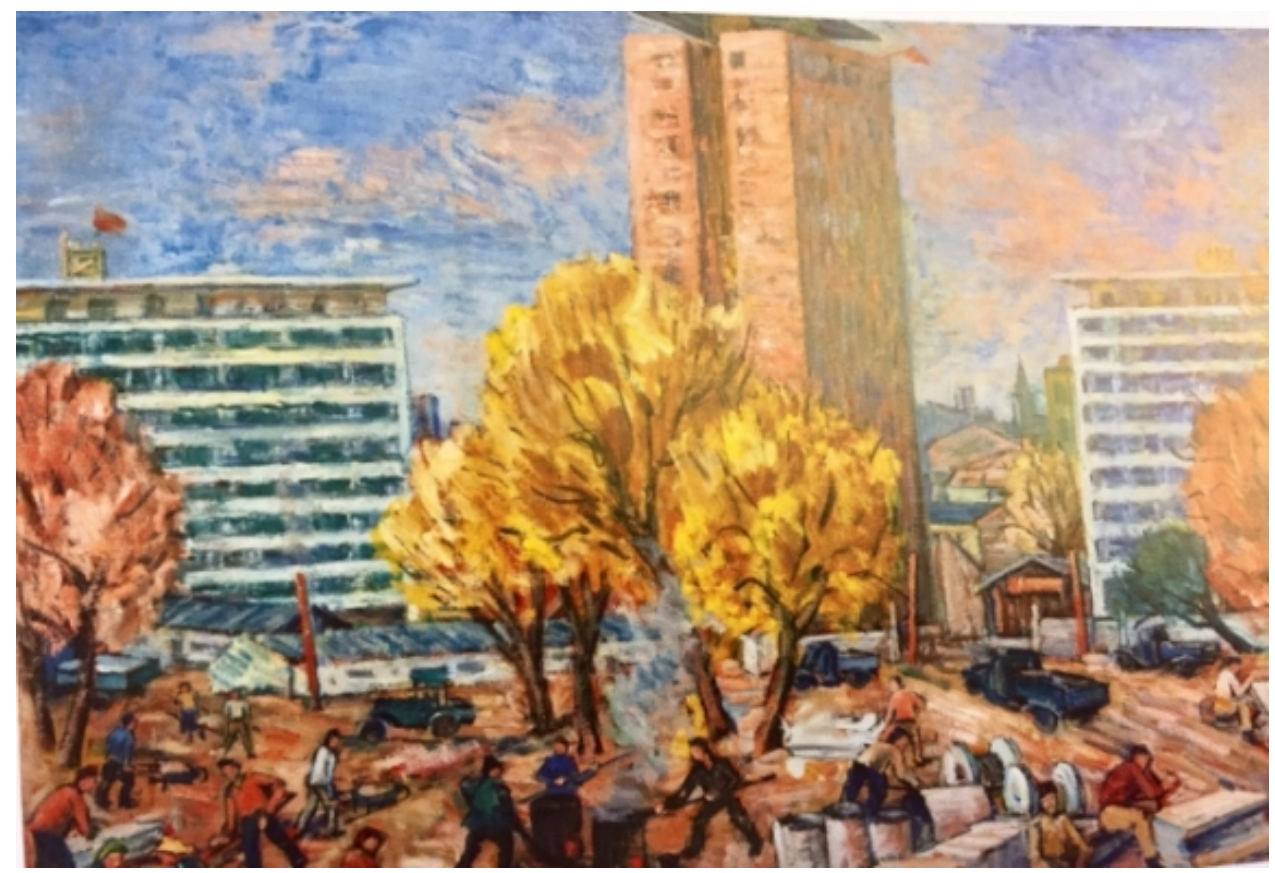

Figure 6. Building the new Bucharest. Marius Bunescu Building site (oil on canvas $0.6 \mathrm{~m} \times 1.87 \mathrm{~m})$.

Source: Credited to Muzeul de Arta al PRP in source (Pictura Românească Contemporană, Editura Meridiane, Bucureşti 1964). Permission being sought from Romanian National Gallery

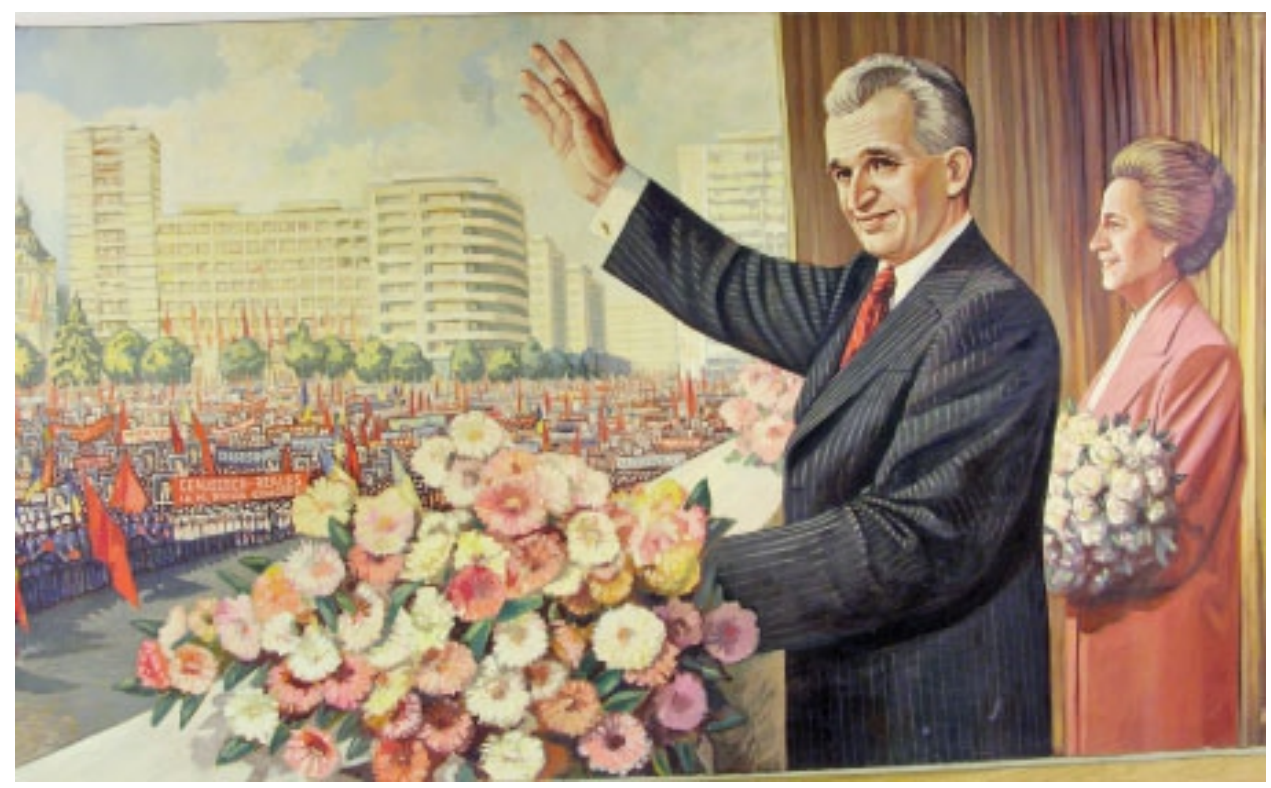

Figure 7. Ceauşescu's city - The Glorious projects.

Source: Painting exhibited in National Museum of Contemporary Art in Bucharest, "Overcoming Dictatorship" 2009. Permission being sought from National Museum of Contemporary Art in Bucharest 


\section{Bob Jarvis}

\section{The socialist city - from rationalism to post-modern (1946 - 1989)}

The image of Bucharest presented in the Communist era is very different from the two periods discussed above - the main reason for this is the almost total control over the painted image that the government was able to enforce through the control of funding. This eventually built up a repertoire of images that glorified the city and the achievements of the Party and latterly more personally of Ceaussescu himself. These were of course not the only images painted, and their several artists had their own, secret oeuvre that offered their own more personal views of the city (Figure 6, Figure 7, Figure 8).

The sense of bleakness at the beginning of this era, before the party control was fully established is shown in the empty and deserted streetscapes of Alexandru Topoia (1914-1993) "the last 'modern classical' of his generation, linking two opposite worlds, one depressed and the other in the making with all the turmoil and anguish of the birth of these times" (Topoia, 1997). His bleak paintings of Bucharest streets are empty of life except for a single figure usually facing into the picture as if these fragmentary scenes might disappear if one were to look away.

In the paintings from the early years of communism, however, there is a sense of looking forward to a bright future for Bucharest; the activities and bustle of construction itself were celebrated. Workmen, pipes, blocks, cranes, timber and trucks all contribute to this sense of working towards a new future which in some of the paintings can be seen rising in the background. This is also apparent in the few 'naive' paintings of urban life included in Artă Naivă in Romania (Savonea, 1980). But the expanding communist city that was emerging was not celebrated in paintings of the vast geometrically laid out housing areas such as Drumul Taberei for instance.
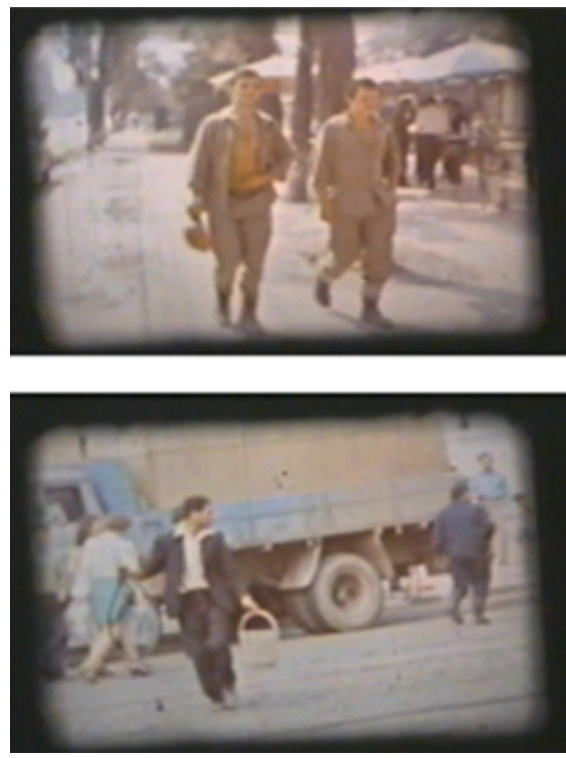

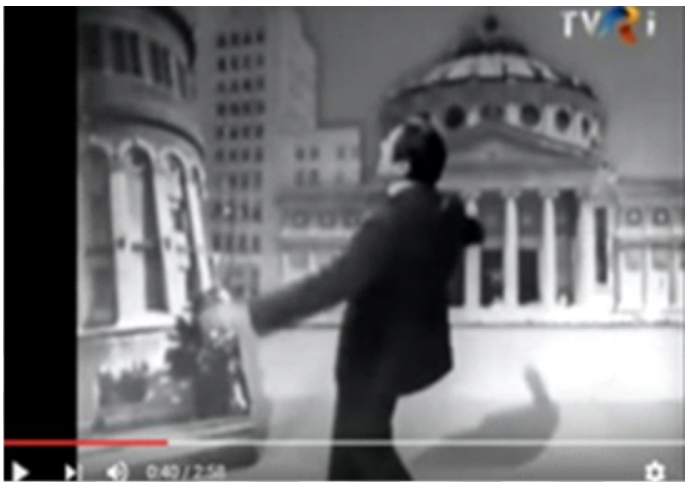

Gica Petrescu - Bucurestiul Meu lubat

"Bucurestiul meu iubit Ce-ai făcut de m-ai vrăjit? "my beloved Bucharest What have you done to get me hooked? București, București, fratele meu ești, Bucharest, Bucharest, my brother you are Bucureşi, București, tu mă veseleşti." Bucharest, Bucharest, you tsar. Gică Petrescu

wuw. voutube.com/watch?V=N1LNaPVhoP8 has the original song in a stage set of Bucuresti TVR

Figure 8. My beloved Bucharest: two versions.

Source: Frames from lon Grigorescu's film (Copyright - Grigor Podnar Gallery, Berlin) 
When Ceauşescu came to power, he began building a new world fit for an idealised 'new man'. A very brief summary of the visual arts in Romania in its 'Golden Age' (A nostalgic half affectionate term for the Ceauşescu years (Mungiu, 2009)) outlines the nature of this control. The National Union of Artists controlled funding for art - and the content of artwork. Without state funding, a few artists avoided this control and therefore could still document the reality but in secret and exhibit work privately. Realistic paintings were impossible and continued only as private works hidden from public display. The use of cameras and home movies, however, was not controlled or licensed by the state, though materials and equipment were not readily available but nevertheless "In Romania under Ceauşescu there didn't exist, as there did in the Soviet Union or Czechoslovakia, any underground cultural movement. There was no samizdat culture. And so there never was a tradition here of cultural liberalism, of cultural resistance. Intellectuals were opportunistic." (Ciupală, 2009).

Savage and extensive urban clearance took place, using the excuse of earthquake risk, in the old centre of Bucharest. From 1974 onwards comprehensive demolitions cleared nearly 1000 acres in the heart of the city, including well established residential quarters of great character and charm, undertaken at very short notice and resulting in significant personal suffering and distress conducted under Ceauseșcu's personal direction with the aim of making a city suitable for his image of 'the new man' (Fearns and Marineacu, 2006). He was influenced in this project by his visits to North Korea, and many commentators suggest that by this point his megalomania was approaching insanity (Fowler, 2017). "With Ceauşescu, everything seems lacking in proportion-his pretension to found a totally other Romania (going as far as the complete modification of the urban and rural landscape and even of geographical equilibria)" (Boia, 2001).

Typically, paintings of Bucharest of this period foreground Ceaușescu being lauded by young Pioneers, the state youth movement, with the new projects in the background. Looking closely at the perspectives and composition of these paintings their artificiality becomes apparent - the foreground figures, the middle ground of adoring crowds and the background of gleaming white new buildings are as if they are three layers painted one over the other rather than a single realistic view.

The approval and rejection of images were very careful, and the example of Ion Grigorescu's triple portrait of Ceauşescu with its implied indecision is a wellknown example. Originally it showed three views of Ceauşescu over a scene of new road construction. Magda Radu (2007) gives a concise account of this: "In 1980, asked to do a portrait of Ceauşescu, Grigorescu was obliged to respond to this request and submitted an intriguing work, which was turned down by the cultural bureaucrats who objected that the portrait did not comply with the strict requirements entailed by Ceaussescu's personality cult, but here his attitudes evince a certain hesitation as if he were pondering over a decision. The artist's intention, as he himself admitted, was to make manifest Ceauşescu's human side."

Ion Grigorescu himself felt strongly about what was happening to the city and made several personal film and photographic pieces in contrast to the official paintings. His short film My Beloved Bucharest takes as its starting point a 
music hall song by Gică Petrescu which uses in the film version artificial cut outs of the recognised famous buildings of the city. In Grigorescu's short film $M y$ Beloved Bucharest "the camera investigates the city's peripheries, testifying to the failure of socialism: the poverty, the dreary living conditions, the new construction projects which gave rise to alienating and low-quality living environments" (Radu, 2007).

Ion Grigorescu made other films and sets of photographs around the estate where he was housed - Balta Alba: The City in Socialism (18 black and white photographs, 1974-1987) Piatra Neamt and Maria at Piatra Neamt (both photographs with oil paint interventions, 1976), Berceni (photograph set 1975), Colentina (colour photographs, 1976), Obor (photographs, 1963, 1979), FundeniDobroieşti (b\&w photographs and colour offset print, 1977), The queue for bread and The queue for sugar (b\&w photographs, 1974) (Şerban, 2013). These photo sets and adapted photographs with layers of painting and additions in contrast to the emptiness of the official views show how even in these bleak peripheral estates human life still went on, however banal and ordinary.

"In his autobiographical work, Grigorescu implicitly questions his role as an artist, a role he already considers achieved in simple everyday gestures.... But that's exactly where their strength lays: the imperfect, raw technique depicts the deep, moving humanity of Grigorescu's works." (Chirulescu, 2010).

Such views of modern Bucharest show the official visions to be false and part of a state propaganda programme. The photographs of Andrei Pandele had a similar role. They were not seen publically and published only in 2008 (Pandele, 2008). In her discussion of 'Forbidden images' Simina Badica notes their power and the way in which the exhibition of Pandele's photographs struck a chord with the visitors and brought back the realities of life under Communism. (Badica, 2014). Pandele had the privileges of being a state architect and was also a trained photographer (Faculty of Journalism, Bucharest, 1978).

"What perspires through the pictures from 1975? Everything is dull and worn-out. A feeling of sadness and beggarliness. The people were dressed in rags; kids in uniforms, only the overcoats are different. Women wear dresses hand sewn or knitted at home. The streets are deserted.... The public transportation was almost inexistent. Even the central arteries were deserted. On Calea Victoriei you could park at any hour. Only the 'Comrade's' portrait was ubiquitous." (Romania Insider, 2010). Mircea Cărtărescu's Nostalgia (1989 in Romanian, translation 2005) captures the suddenness and confusions of the massive redevelopments of this era, and, from a child's perspective the opportunities this gave for adventure while the city is torn apart.

\section{Post-1989 - the difficult return to Europe}

The sudden collapse of the Communist state left a vacuum in the arts. The result was a huge and confusing output in a wide range of media paralleling and documenting the chaos of the suddenly interrupted communist project on the urban landscape of Bucharest (Figure 9, Figure 10).

The work of Stefan Constantinescu makes an appropriate point to start. The sunny glow of An Infinite Blue a series of 22 paintings showing idealised images 


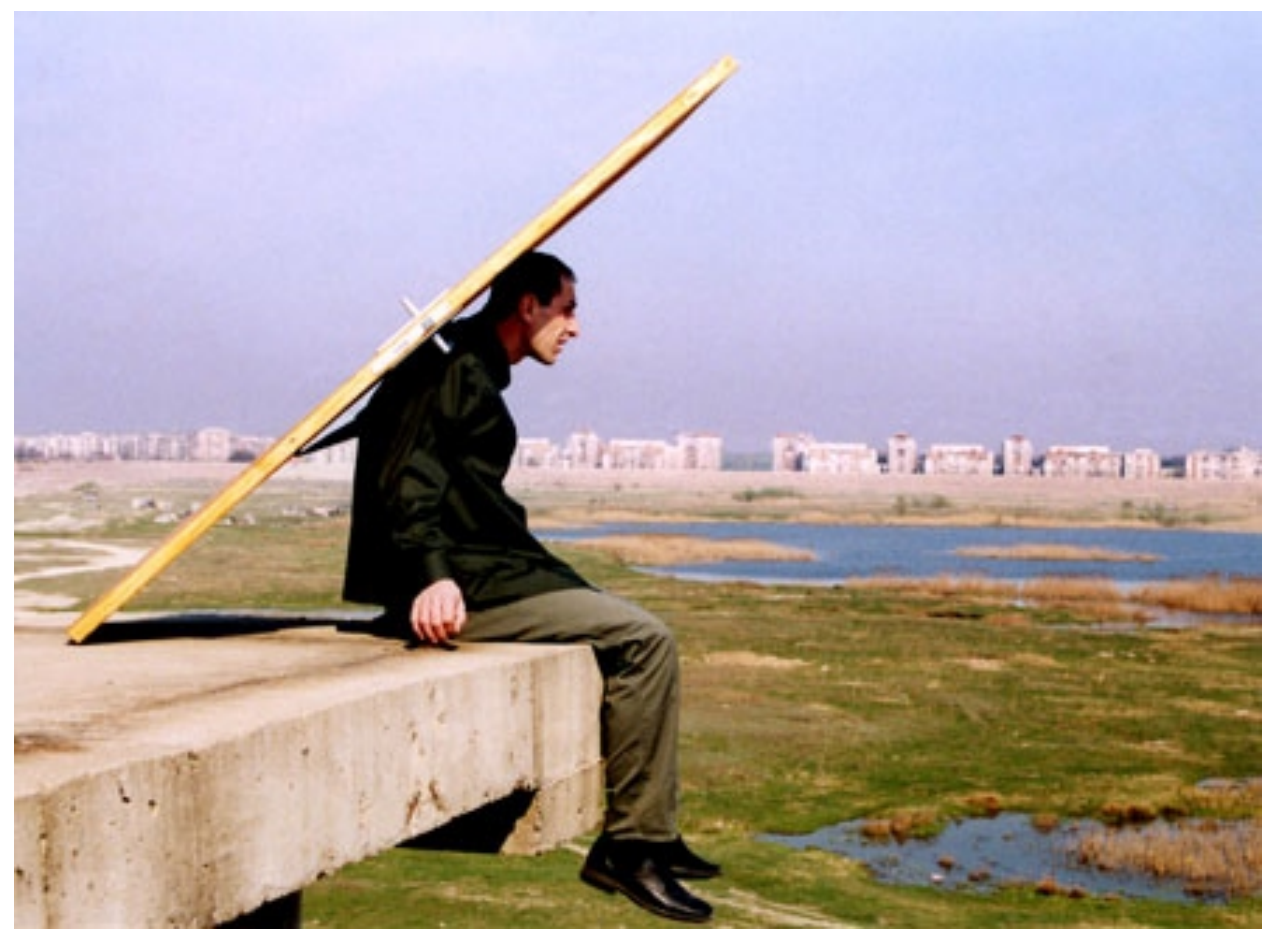

Figure 9. Sample City.

Source: https://vimeo.com , Calin Dan , Videos (Permission from Calin Dan at MNAC)

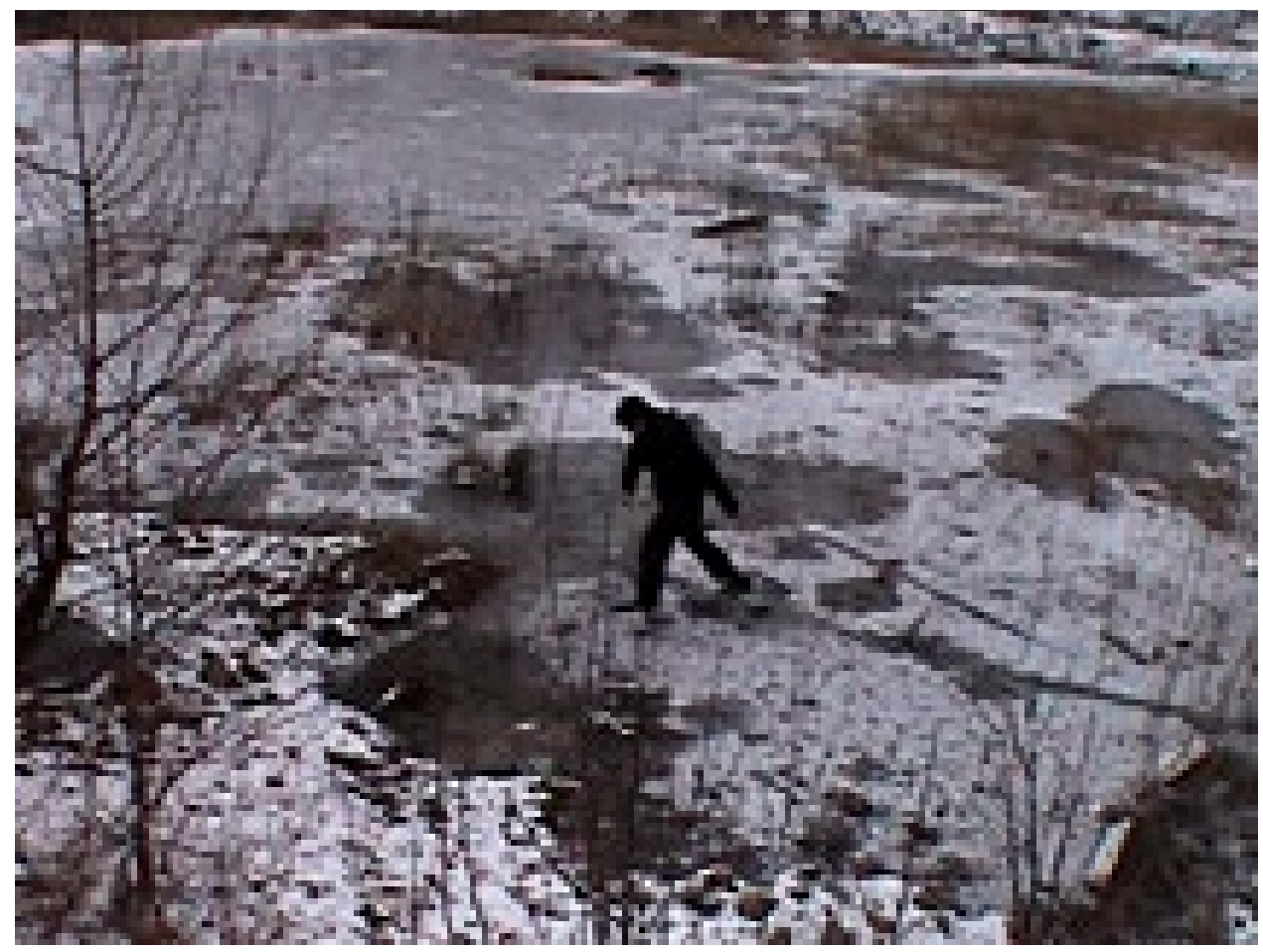

Figure 10. Mona Vatamanu \& Florin Tudor Văcăreşti.

Source: www.lombardfreid.com/vatamanu-tudor/. Still from video. (permission from LFC Agency, New York) 
of Communist Bucharest, based on propaganda pictures from the 1960s echoes the 'ost-nalgie' idea of this period being a 'golden age'. Constantinescu (2008) has developed this explicitly in his pop-up book The Golden Age for Children which includes several ironic commentaries on Bucharest with moveable flaps and sliding inserts which features the artists' biography intertwined with highlights from the grand narrative. The story begins in 1968, the year Sttefan Constantinescu was born and ends with the Revolution in 1989.

"In retrospect, the most obvious thing about Ceauşescu' s golden age was its fraudulence...... Dense and provocative, 'Ostalgia' is richly 'underground' - an array of unmarketable underdog art, infused with forbidden impulses, all, however obsessively private, unavoidably political." (Hoberman, 2011).

Ion Grigorescu continued to produce commentaries on the upheavals that had occurred in the city. One of the most memorable is a second retracing of the walk that he took obliquely across the 'Vitan Ceausescu' - the new great straight axis leading to the new 'palace' made initially as Drumul Nou axa a oraşului (the new road axis to the town) 1993 which although included in the Out of Place exhibition at Tate Modern in 2011 and listed in his works it has proved untraceable. The later version shows the changes frozen with the collapse of communism and tracing a route that Grigorescu took diagonally across the city to reach the church he was restoring shows the ways in which the chaos that is regrowing in the city was overunning the grand plan.

The collective SubReal a 'group of action' appeared as a consequence of the political changes, to "exorcise the residue of the decades of communist oppression" (MNAC, 2012). In one series a number of carefully composed photographs called Framing Bucuressti in which they held up an elaborate frame around a view showing quite an ordinary post-communist scenes as if they were actually worth framing (Manca, 2012).

Călin Dan is a key figure in contemporary Romanian art: he is now Director of MNAC (Romanian Museum of Contemporary Art) and has commented on the changing nature of the city and Bucharest, in particular, the way the centre had become a series of slogans (Angel, 2004). His film Sample City takes a piece of Romanian folklore to offer a strange narrative journey through this broken landscape.

"It is the story of Păcală (sort of Romanian Tijl Uilenspiegel) who - told by his brothers to 'pull the door behind you when you leave the house' - reacts ad literam and starts off carrying the door on his back." (ehituskunst, 2013).

Nicolae Comenescu is one of the best known and most prolific figurative painters in Romania. What makes his work of special interest here is the shift in his style of work from about 2007 from a garishly coloured roughly painted super-realist/surrealistic transatlantic style in which fragments of the landscape of Bucharest were collaged and transformed into a kind of American dreamscape to realistic and grubby landscapes of the seemingly endless blocuri painted with the dust that permeates the city: "it's a dust that comes from their bricks and mortar, and from the peeled and fallen painting, and from the dusty streets, alleys and green areas nearby.

The metaphysical sadness of the unfamiliar blocks of flats crosses the image fixed in dust more than in a photograph." (Tiron, 2007). Many of Mona 
Vatamanu and Florin Tudor works' are haunted by the strange landscapes left from the communist era, documented at the time when these abandoned places were mysterious and unexplained. Today the relics of this era are gradually being demolished, rebuilt or converted (Light and Young, 2010).

Their film of the trial of the Ceauşescu's Procesul (2004-2005), shows a "mesmerising succession of serial socialist buildings in Bucharest, filmed from a moving car. The soundtrack accompanying these views is a monotonous reading of the transcript of Nicolae and Elena Ceaussescu's kangaroo trial in December" (Costinas, 2012) - still drab 15 years after the revolution.

In Văcăreşti parts of which can be found online filmed in dark winter ice and snows from 2004 to 2006 shows an attempt to retrace the outline of the famous Văcăreşti Monastery built in 1716-1722 by Nicolae Mavrocordat in Brâncoveanu style but the sense of loss and mystery of the site is central. "After the fall of the communist regime in Romania there were talks about reconstructing the monastery, but nothing happened..... It's like a whole community of people don't have the ability to link with their own past. Where the monastery once existed, there are socialist ruins....., an empty lake and big empty spaces. We went there and tried to draw, map, using wooden sticks and wire, the shape of the church. None of us saw before the real monastery and church." (Vantamanu and Tudor).

The palace/Persepolis combines a (secretly made) film of a guided tour of the newly opened 'Palace' with images of the 'new' Bucharest. Their Artists statement gives a strong impression of the work: "We can't describe the horrific dimension that this building represents for us, maybe ridiculous, incoherent, absurd, aggressive could be the words." (Vatamanu and Tudor, 2004).

Writing too became more experimental. Filip and Matei Florian's The Băiuț Alley Lads (Baiuțeii in Romanian translation) presents a multi-layered and double authored account of growing up in Bucharest and even offers alternative endings.

Although the post-communist period has laid over the past cities a seemingly uncontrolled urban landscape it is the mysterious unfinished and abandoned relics of the communist era that still haunt many contemporary artists, by providing a source of inspiration and reflection in much the same way as the relics of classical Rome offered inspiration to artists of the 17 th and 18th centuries.

\section{Conclusions}

This small study of the new capital of a new country has demonstrated how the evolution of visual art (and literature) are intertwined with the evolution of place and the changing eras of its development and can provide an enriched perspective which brings a widened perspective to discussion of urban development as well connecting study of the arts into connection with geographical researches. Romania and Bucharest, because of the particular nature of their development and the quite precise timescales involved have provided an excellent basis for this exploration. 


\section{References}

Adameșteanu, G. (2011/1984), A wasted afternoon (Dimineaţă pierdută), Translated by Patrick Camiller, Northwestern University Press.

Angel, J. (2004), "Mobility is my only way of being around...An interview with Calin Dan", Idea: Arte +Societa, no. 17, 5 September 2017, (https://goo.gl/wnm36Y).

Armanca, A. (2012), Subreal reality, 11 May 2007, (https://goo.gl/rFY2rr).

Badica, S. (2014), 'Forbidden images?' Visual memories of Romanian Communism before and After 1989.

Boia, L. (2001), History and Myth in Romanian Consciousness, Budapest: Central European University Press.

Busuioceanu, A. (1930), Iser, Craiova: Ramuri.

Călinescu, G. (1986) Istoria literaturii române de la origini pînă în prezent, Bucharest: Editura Minerva

Cârneci, M. (1989), Lucian Grigorescu, Bucharest: Editura Meridiane.

Cărtărescu, M. (1989/2005), Nostalgia (translated by Julian Semilian), New Directions.

Chirulescu, M. (2010), "Films by Ion Grigorescu - film screening on the occasion of the exhibition by Marieta Chirulescu", Kunsthalle Basel, 26 October 2010, (https://goo.gl/8wjzpT).

Cina, G. (2010), Bucuressti, de la stat la metropolita/Bucharest, from village to metropolis, Bucharest: Capitel Collectia Biblioteca de Architectura/Memoria Oraselor.

Ciupala, A. (2009), "Romania Shrugs Off Reminder of Its Past New York in Art \& Design", Times, no. February 25.

Costinaş, C. (2012), Surplus, Value Art Daily.org, no. August 13.

Deac, M. (1962), Jean Al. Steriadi, Bucharest: Meridiane.

Ehituskunst (2013), Construction Arts, Estonian Academy of Arts, 26 October 2010, (https://goo.gl/ik7rpE).

Eliade, M. (2016), Novel/diary of a short sighted adolescent (Romanul adolescentului miop) (translated by Christopher Moncrieff and Christopher Bartholemew), London: Istros Books.

Fearns, R. and Marinescu, R. (2006), Off the map film, Romanian Cultural Institute 2006.

Florea, V. (1983), Romanian Painting, Detroit: Wayne State University Press.

Florian F. and Florian M., (2010), The Băiuţ Alley Lads, (Translated by Alistair Ian Blyth), University of Plymouth Press.

Fowler, M. (2017), 'How 7 Dictators Used Buildings to Influence and Intimidate', ArchDaily, 12 June 2017, (https://goo.gl/BXHVTm).

Hoberman, J. (2011), The Good Old Days: Tales From the Golden Age and "Ostalgia", New York: Village Voice.

Iancu, M. (2010), Bucharest and its utopia (originally Towards an Architecture for Bucharest 1935) translated and edited by N Lascu and F Vogel, 2010 Handlung: on producing possibilities - reader of Bucharest Biennale 4, Bucharest: Pavillion, p. 362- 373.

Ionescu, N. (ND), Adevărul despre Micul Paris în fotografile lui Nicolae Ionescu, 12 June 2017, (https://goo.gl/2X65Ah).

Janco, M. (1926), 'The Bucharest of Accidents', Contimporanul, vol. 70, no. 9 (in 
translation). The Romanian original (Bucureştii accidentelor ), 12 June 2017, (https://goo.gl/w19FLh)0

Kaufmann, T.D. (2000), "Borders In Art: Revisiting 'Kunstgeographie'" K Murawska-Muthesius (ed), Proceedings of the Fourth Joint Conference of Polish and English Art Historians, Norwich: University of East Anglia.

Kaufmann, T.D. (2004), Toward a Geography of Art Chicago, University of Chicago Press

Kessler, E. (2011), Retroguardia in E. Kessler and I. Vlasiu (eds).

Kessler, E. and Vlasiu, I. (eds) (2011), I colori delle Avanteguardie Arte in Romania 1910-1950 /The Colours of the Avant Garde in Romanian Art 1910-1950, Rome: Gangemi Editore.

Light, D. and Young, C. (2010), "Reconfiguring socialist urban landscapes: the 'left-over' spaces of state-socialism Bucharest", Human Geographies - Journal of Studies and Research in Human Geography, vol. 4, no. 1, p. 5-16.

Machedon, F., Machedon, L. and Scoffham, E. (1999), "Inter-war Bucharest: city in a garden", Planning. Perspectives, vol. 14, no. 3, p. 249-275.

Magda, R. (2007), "Art and Politics: considering some of Ion Grigorescu's films and photographs", Paper presented at Technology and photography in transition - International Symposium (Conference - New Europe College, Bucharest), 11 May 2007, (https://goo.gl/YLW8ya).

Mansbach, S. (1998), Modern Art in Eastern Europe Cambridge, Cambridge University Press.

Members of the Central Research Institute for Building Architecture and Planning (ISCAS) (1972), "Urban Development in Romania" in E.A. Gutkind (ed) (1972) Urban Development in Eastern Europe, New York: Free press.

MNAC (2012), subREAL Retrospect, Bucharest: National Museum of Contemporary Art.

Muncenic, C. (2004), Străzi, Piețe, case din Vechiul Bucureşti, Bucharest: Editura Vrema XXI.

Mungiu, C. (2009), Tales from the Golden Age (Amintiri din epoca de aur), film France/Romania, Distributor Wild Bunch.

Murawska-Muthesius, K. (ed) (2000), "Borders in Art: Revisiting 'Kunstgeographie"', Proceedings of the Fourth Joint Conference of Polish and English Art Historians, University of East Anglia, Norwich, 1998, Warsaw: Institute of Art.

Pandele, A. (2008), Martorul - Surpriză: fotografii necenzurate din comunism/Surprise Witness - uncensored photos from the Communist years, Bucharest: Compania.

Pavel, A. (1996), Pictori evrei din România, Bucharest: Editura Hasefer.

Pevsner, N. (1956), The Englishness of English Art, Harmondsworth: Penguin.

Prut, C. (2016), Dictionar de artă modernă şi contemporană, Bucharest: Editura Polyrom.

Purcar, C. (2015), "At Home by the Tracks. Domesticity in Proximity of Railway Space in (Early) Modern Art 1", Acta Technica Napocensis: Civil Engineering ${ }^{\circ}$ Architecture, vol. 58, no. 4.

Reed, J. (1916), The War in Eastern Europe, 11 May 2007, (https:/goo.gl/8ZL596). romania-insider (2010), Book Insider: Forbidden photos and personal images by Andrei

Pandele, 11 May 2007, (https://goo.gl/yGzxwx).

Sandquvist, T. (2006), DadaEast, Boston: MIT. 


\section{Bob Jarvis}

Savonea, V. (1980), Arta Naiva in Romania, Bucharest: Meridian.

Sebastian, M. (1936/2016), For two thousand years, Harmondsworth: Penguin.

Serban, A.(ed) (2013), Ion Grigorescu - the man with a single camera, Berlin: Sternberg Press.

Sterian, M. (2008), "Century journal - Margareta Sterian", EU - Screen, 11 May 2007, (https://goo.gl/91TPqo).

Tiron, S. (2007), "Nicolae Comănescu does not remove dust", HotNews, 11 May 2007, (https://goo.gl/ZGDDJK).

Todorova, M et al. (2014), Remembering Communism Budapest, CEU Press, p. 201216.

Tudor, O. (2000), Bucureştiul Interbelic/Calea Victoriei, Bucharest: NOI Media Print

Tzipoia, G. (1997), Alexandru Tipoia, 1914-1993, Paris: Alp impr.

Uniunea Arhitecţilor din România (1994), Bucureşti anii 1920-1940: Intre avangardă şi modernism Bucharest.

Vatamanu, M. and Tudor, F. (2004), The palace/ Persepolis 2020 Home Gallery, Bucharest, 14 April 2004, (https://goo.gl/AHUp9r).

Vatamanu, M. and Tudor, F. (ND), Văcăresti, 14 April 2004, (https://goo.gl/xNZ8fo).

Vlasiu, I. (2011), "City life versus rural life in Interwar Romanian Painting" in E. Kessler and I. Vlasiu (eds) 2011. 